\title{
A Sight Record of Yellow-legged Herring Gull from Kyushu, Japan
}

\author{
Mark BRAZIL
}

Gulls are both interesting and easily watched, however, they are frequently overlooked. They often occur in large numbers, especially at winter roosts, and unusual individuals may be missed under the assumption that the whole flock is comprised of a single species. As with flocks of other species, such as waders or warblers, a detailed search often proves this assumption wrong.

After years of meticulous observation by numerous observers the details of the identification, age and moult of Gulls occurring in the western Palearctic have been excellently summarized by GRANT (1982), making identification much easier for future observers. It is unfortunate that no such work covers the species ocurring in the eastern Palearctic. Japan, as a chain of islands in the west Pacific close to the Asian continent is a particularly interesting place to study Gulls and 15 species have been recorded so far (WBSJ, 1982). This short note is presented in the hope of stimulating a greater interest in the gulls of Japan, their populations and movements.

During a visit to Ariake Bay, Kyushu I was particularly interested in the various species of gulls Larus sp. which were in the area. The recent presence of a Great Black-headed Gull L. ichthyaetus and the presence of at least seven Sanuders's Gllus L. saundersi in a variety of plumages, made checking through the gulls a more than usually interesting task.

On 21 March 1983 I located a flock of approximately 50 Herring Gulls $L$ argentatus and 50 Blackheaded Gulls $L$ ridibundus on a mudflat at Isahaya, on the west side of Ariake Bay. A single first winter Black-tailed Gull $L$. crassirostris was also in the area and was the only one recorded during a three day observation period. On looking through the Herring Gull flock, which was resting on the mud about $200 \mathrm{~m}$ out from the sea wall (I was using $10 \times 40$ binoculars) I came across a bird with apparently yellow legs and soon after found a second. On changing to a $20 \times$ field-scope I was able to confirm that they both had yellow legs and also unusually bright yellow bills with prominent red spots.

The subspecies of Herring Gull known to occur in Japan is L. a. vegae which has pink legs. I was able to compare the two yellow-legged birds directly with nearby $L$. $a$. vegae, but was unable to detect any differences in size or plumage. Their mantles and wings appeared to be the same shade of grey as those of L.a. vegae, however, the soft parts were noticeably different. Their legs were bright yellow, although not the same shade as, for example, those of the Black-tailed Gull which I would describe as lemon-yellow, instead they appeared to be yellow-ochre. Their bills were a richer, more orange-yellow than those of nearby $L$. a. vegae and the red bill spots were especially bright and prominent.

The initial possibilities which I considered were that the two birds were either a different subspecies of the Herring Gull or perhaps a vagrant North American species hitherto unrecorded in Japan. Of the latter only one species seemed to have the potential for confusion with the Herring Gull and the potentiality for vagrancy to Japan, namely the California Gull $L$. californicus which is a migratory species occurring in the western U.S.A.

However, this species is smaller than the Herring Gull, has greenish-yellow legs and a black spot, as well as a red spot on the bill (see RoBbins et al., 1966) hence my observations ruled this species out. I then consulted the available literature for further details concerning Herring Gulls, but the recent fieldguide (WBSJ, 1982) includes no details of subspecies of the Herring Gull, and OSJ (1974) records none of the yellow-legged subspecies for Japan. GRANT (1982), however, provides identification details for both the northern and southern groups of subspecies. My field description matches closely with his description of L. a. mongolicus. L. a. mongolicus is the easternmost of the southern group and its winter range is not fully known although it 'includes at least coastal China' (GRANT, 1982), in fact both L. a. vegae and L. a. mongolicus roots together in large numbers in Hong Kong (VINEY \& PHILlipps, 1979). 
Although a sight record, unsupported by a specimen or photograph, is not sufficient for addition to the Japanese list (MoRIOKA, pers. comm.), it would appear that this is the first published record of this sub-species for Japan. Closer observation of Gulls in the future may show that the Isahaya case was not an isolated occurrence. Herring Gulls have also been recorded as rare migrants or vagrants from the southern Japanese islands (I was able to observe a single adult at Miyako Island in December 1982, for example) and also from Taiwan (YEN, 1979). Closer observation of Herring Gulls in this region may help to establish the wintering range of this sub-species.

The taxonomy of the Herring Gull is in some dispute, with some authors affording the southern 'cachinnans' group full specific status as the Yellow-legged Gull L. cachinnans (e.g. CLEMENTS, 1981). Others including GRANT (1982) record them as a group of sub-species of the Herring Gull. Should specific status become more generally acceptable for the yellow-legged gulls, then this record would in fact represent a new species for Japan.

Summary: Two Herring Gulls with yellow legs were observed on 21 March 1983 at Isahaya, Kyushu, Japan. A field description based on a comparison with Larus argentatus vegae, which were also present, leads to the conclusion that they were $L$. a. mongolicus a sub-species not previously recorded in Japan. (Author's address: Rakuno Gakuen University, 582 Nishi-Nopporo, Ebetsu, Hokkaido 069-01, Japan.)

\section{LITERATURE CITED}

Clements, J. F., 1981. Birds of the World: a checklist. 3rd ed. New York, Facts on File.

Grant, P. J., 1982. Gulls: a guide to identification. Calton, Polyser.

ORNIthological Soctety of JAPAN (OSJ), 1974. Checklist of Japnaese Birds. 5th ed. Tokyo, Gakken.

Robitns, C. S., B. BruUn, H. S. Zim \& A. Singer, 1966. Birds of North America. New York, Golden Press.

Viney, C., \& K. Phillipps, 1979. A Colour Guide to Hong Kong Birds. 2nd ed. Hong Kong, Government Printer.

Wild Bird SocietY of JAPAN (WBSJ), 1982. A Field Guide to the Birds of Japan. Tokyo, WBSJ. Yen, Chung-weI, 1979. A New Checklist of Taiwan Birds. Taichung, Tughai University.

九州諫早海岸で Yellow-legged Herring Gull を観察 1983 年 3 月 21 日, 九州諫早海岸にて野鳥観 察中に，約 50 羽のセグロカモメ Larus argentatus vegae の群れに混じった 2 羽の足の黄色いカモメを 認めた. 同群のセグロカモメと比較観察の結果, この 2 羽はセグロカモメとは亜種が異なる Yellowlegged Herring Gull Larus argentatus mongolicus と同定できた. この亜種は日本からは未記録であ る. - Mark BRAZIL (北海道酪農学園大学). 